\title{
PERMINTAAN PANGAN RUMAHTANGGA PROVINSI RIAU: MODEL LINEAR APPROXIMATE ALMOST IDEAL DEMAND SYSTEM
}

\author{
Heriyanto Heriyanto \\ Program Studi Agribisnis Fakultas Pertanian Universitas Islam Riau \\ Jl. Kaharuddin Nasution 113, Pekanbaru 28284-Riau \\ Telp. : 0761-72126 ext. 123, Fax : 0761-674681 \\ Email: heriyanto@agr.uir.ac.id
}

\begin{abstract}
ABSTRAK
Penelitian ini bertujuan untuk: Menganalisis pola konsumsi pangan rumahtangga menurut tingkat pendapatan dan pendidikan, dan prilaku konsumsi pangan pokok pangan pokok rumahtangga Provinsi Riau. Untuk menjawab tujuan penelitian ini dibangun model Linear Approximate Almost Ideal Demand System (LA-AIDS) dengan metode Seemingly Unrelated Regression (SUR). Komoditas pangan pokok yang dimasukkan dalam model mencakup tujuh komoditas meliputi: beras dan sagu, susu, daging sapi dan ayam, garam, gula pasir, minyak goreng, serta sayur-sayuran dan buah-buahan. Hasil penelitian menunjukkan bahwa semakin tinggi tingkat pendapatan, proporsi pengeluaran pangan cenderung menurun. Semakin tinggi pendidikan ibu rumah tangga semakin banyak pula konsumsi susu, daging sapi dan ayam, sayur-sayuran serta buah-buahan, sedangkan konsumsi beras dan sagu, gula pasir, dan minyak goreng cenderung menurun. Sebahagian besar estimasi parameter harga komoditas dan pendapatan rumahtangga dominan mempengaruhi tingkat konsumsi untuk setiap kelompok komoditas. Hasil elastisitas harga pada seluruh komoditas yang diamati bertanda negatif dan tidak responsif terhadap perubahan harganya. Demikian juga halnya, elastisitas silang menunjukkan pengeluaran konsumsi masing-masing komoditas yang diamati tidak responsif terhadap perubahan harga komoditas lainnya. Sedangkan elastisitas pendapatan, terdapat dua komoditas yaitu daging sapi dan ayam, serta sayur-sayuran dan buah-buahan, responsif terhadap perubahan pendapatan. Dari temuan tersebut, dapat dinyatakan bahwa kebijakan yang berkaitan dengan upaya peningkatan pendapatan lebih baik dilakukan dibandingkan dengan kebijakan pengendalian harga. Upaya untuk memperbaiki pendapatan rumahtangga penting dilakukan untuk meningkatkan konsumsi masyarakat, khususnya konsumsi daging sapi dan ayam, serta sayur-sayuran dan buah-buahan.
\end{abstract}

Kata kunci: Pangan Pokok, Prilaku Konsumsi, Elastisitas

\section{PENDAHULUAN}

Terjaminnya ketersediaan pangan dalam jumlah yang cukup, kualitas yang memadai dan tingkat harga yang terjangkau oleh rumahtangga merupakan sasaran dan target yang ingin dicapai dalam penyusunan dan perumusan kebijakan pangan nasional. Ketidakstabilan persediaan pangan dan/atau gejolak harga pangan pokok, kekurangan beras di Indonesia telah terbukti dapat memicu munculnya gejolak nasional yang mengarah pada tinda1k kriminal. Ada beberapa kebijakan pemerintah yang pernah dilakukan dalam mengendalikan harga pangan, misalnya pengendalian harga beras melalui bulog, operasi pasar untuk mengendalikan minyak goreng, impor untuk mengendalikan harga gula dan terigu. Kebijakan pemerintah dalam peningkatan diversifikasi

156 Permintaan Pangan Rumahtangga Provinsi Riau: Model Linear Approximate Almost Ideal Demand System 
pangan juga telah dilakukan mengacu pada Peraturan Presiden Nomor 22 Tahun 2009 dan Peraturan Menteri Pertanian Nomor 43 Tahun 2009 tentang peningkatan keanekaragaman pangan sesuai karakteristik daerah sebagai acuan yang dapat mendorong percepatan penganekaragaman konsumsi pangan (P2KP) berbasis sumberdaya lokal melalui kerjasama sinergi antara pemerintah pusat dan pemerintah daerah.

Secara teoritis, permintaan terhadap suatu komoditas atau kelompok komoditas dipengaruhi oleh harga komoditas yang bersangkutan, harga komoditas lain yang memiliki hubungan dengan komoditas tersebut, tingkat pendapatan dan selera. Menurut Koutsoyianis (1979); Lipsey (2013); Pindyck dan Rubinfeld (2014), secara konseptual permintaan merupakan suatu fungsi yang dipengaruhi oleh banyak peubah (multivariate). Peubah-peubah penting yang mempengaruhi permintaan adalah harga barang yang bersangkutan, harga barang lain, pendapatan serta selera. Ischak, (2005), dalam analisis jangka pendek dapat diasumsikan tidak terdapat perubahan selera, oleh karena itu konsumsi dan permintaan suatu komoditas ditentukan oleh tingkat harga-harga dan pendapatan. Apabila harga-harga disuatu wilayah diasumsikan homogen, dapat dihipotesiskan bahwa penduduk (rumahtangga) yang memiliki tingkat pendapatan berbeda akan memiliki pola konsumsi dan permintaan yang berbeda pula. Masalah utama yang mempengaruhi permintaan dan konsumsi pangan, yaitu harga komoditas yang bersangkutan berfluktuasi dan cenderung meningkat, ketersediaan bahan makanan semakin terbatas, tingkat pendapatan dan selera masyarakat yang selalu berubah. Oleh karenanya kajian yang berkaitan dengan pola konsumsi dan faktor-faktor yang mempengaruhi pengeluaran pokok rumahtangga sangat diperlukan sebagai bagian yang tidak terpisahkan dengan upaya mewujudkan ketahanan pangan nasional.

Secara umum penelitian ini bertujuan untuk menganalisis pola dan perilaku konsumsi pangan oleh rumahtangga di Provinsi Riau. Secara spesifik bertujuan untuk : (1) Menganalisis pola konsumsi pangan rumahtangga menurut golongan pendapatan (rendah, sedang dan tinggi) dan pendidikan di Provinsi Riau, dan (2) Menganalisis Faktor dominan yang perilaku konsumsi pangan pokok rumahtangga

\section{METODE}

\section{Jenis dan Sumber Data}

Jenis data yang digunakan dalam penelitian ini adalah data sekunder yaitu data Survei Sosial Ekonomi Nasional (SUSENAS) tahun 2016. Data tersebut merupakan data penampang lintang (cross section) yang bersumber dari Badan Pusat Statistik (BPS).

\section{Spesifikasi Model}

Model yang digunakan adalah aproksimasi linear dari Model Almost Ideal Demand System (AIDS) yang merupakan modifikasi dari model yang dikembangkan oleh Muelbauer (1980) selanjutnya Blanciforti dan Richard, (1983). Dipilihnya model ini karena model sistem permintaan lebih mampu mengadopsi fenomena perilaku konsumen dalam mengkonsumsi suatu komoditas, 
dimana komoditas yang dikonsumsi rumahtangga bermacam-macam dan saling terkait satu dengan yang lainnya. Keputusan untuk mengkonsumsi suatu komoditas akan berpengaruh pada tingkat konsumsi komoditas lainnya. Modifikasi model AIDS dilakukan dengan memasukkan peubah jumlah anggota rumahtangga, tingkat pendidikan ibu rumahtangga dan golongan pendapatan rumahtangga. Model LA/AIDS tersebut diformulasikan sebagai berikut :

$$
W i=a_{i}^{*}+\sum_{j} v i j \log P j+\beta i \log \left(X / P^{k}\right)+\theta i S+d_{1 i} D_{1}+d_{2 i} D_{2}+d_{3} D_{3}
$$
dimana :
$\mathrm{i}, \mathrm{j}=1,2, \ldots, 8$, yang masing-masing menunjukkan kelompok komoditas beras dan sagu, dan Garam beriodium. gula pasir, sayur-sayuran dan buah-buahan, daging sapi dan ayam, minyak goreng, susu,
$\mathrm{Wi}=$ Pangsa dari kelompok pangan ke-i terhadap total pengeluaran pangan $(\mathrm{wi}=$ piqi $/ \mathrm{x})$.
$\alpha, \beta, \gamma, \theta,=$ Parameter regresi berturut-turut untuk intersep, pengeluaran, harga agregat, jumlah anggota keluarga, untuk masing-masing komoditas.
$\mathrm{Pj} \quad=$ Harga tertimbang kelompok pangan $\mathrm{ke}-\mathrm{j}\left(\mathrm{Pj}=\sum \mathrm{WkPk}\right)$.
$\mathrm{X}=$ Pengeluaran total kelompok pangan pokok.
P* $\quad=$ Indeks harga Stone, dimana $\log \mathrm{P}^{*}=\sum$ wi $\log$ pi.
$\mathrm{S}=$ Jumlah Anggota rumah tangga.
$\mathrm{D}_{1} \quad=$ Dummy Pendidikan; $\mathrm{D}_{1}=1:$ Pendidikan tinggi; $\mathrm{D}_{1}=0:$ lainnya
$\mathrm{D}_{2} \quad=$ Dummy Pendapatan; $\mathrm{D}_{2}=1:$ Pendapatan rendah; $\mathrm{D}_{2}=0:$ Pendapatan lainnya
$\mathrm{D}_{3} \quad=$ Dummy Pendapatan; $\mathrm{D}_{3}=1:$ Pendapatan tinggi; $\mathrm{D}_{3}=0:$ Pendapatan lainnya

\section{Prosedur Analisis Data}

\section{Metode Pendugaan Model}

Pendugaan parameter model LA/AIDS dilakukan untuk mengetahui faktor-faktor dominan yang mempengaruhinya pengeluaran konsumsi pangan pokok rumahtangga di Provinsi Riau. Metode analisis yang digunakan adalah metode Seemingly Unrelated Regression (SUR). Penelitian terdahulu pendugaan parameter dengan menggunakan model LA/AIDS adalah [6][21][22], [23].

\section{Restriksi}

Untuk memenuhi teori permintaan, dalam pendugaan model LA/AIDS tersebut diterapkan restriksi-restriksi sebagai berikut [24]-[31]:

(i) Simetri : $\gamma \mathrm{ij}=\gamma \mathrm{ji}$

(ii) Homogenitas : $\Sigma_{j} \gamma i j=0$

(iii) Adding-up : $\sum_{i} \alpha i=1, \sum_{i} \gamma i j=0, \sum_{i} \beta i=0, \sum_{i} \theta i=0, \quad$, (4)

\section{Uji Asumsi Ekonometrik}

Agar memberikan hasil yang valid secara ekonometrik perlu dilakukan pengujian beberapa asumsi ekonometrika yang meliputi pendekteksian normalitas dan heteroskedastisitas dari setiap persamaan dalam model. Pendeteksian normalitas menggunakan Shapiro-Wilk test, dan pendeteksian masalah heteroskedastisitas menggunakan Breusch-Pagan test ([26], [28], [30], [31].

\section{Perhitungan Nilai Elastisitas.}

Elastisitas harga sendiri, elastisitas harga silang dan elastisitas pendapatan di rumuskan 
sebagai berikut [1]-[3], [32], [33]:

1. Elastisitas harga sendiri :

$$
e_{i i}=\frac{y_{i j}-\beta_{i} W_{i j}}{w_{i}}-1
$$

2. Elastisitas harga silang :

$$
e_{i j}=\frac{y_{i j}-p_{i} W_{i}}{W_{i}} ;(i \neq j) \text {. }
$$

3. Elastisitas pengeluaran (pendapatan) :

$$
\eta_{i}=\frac{\beta_{i j}}{W_{i}}+1
$$

\section{HASIL DAN PEMBAHASAN}

Dari tujuh persamaan pangsa pengeluaran pangan pokok yang dianalisis dari tujuh komoditas (kelompok komoditas) pangan pokok terpilih, yaitu: beras dan sagu, susu, daging sapi dan ayam, garam, gula pasir, minyak goreng, sayur-sayuran dan buah-buahan. Terhadap pendugaan tujuh persamaan pangsa pengeluaran tersebut dilakukan uji restriksi pada beberapa parameter yang memenuhi persyaratan adding up, homogenitas dan simetris. Selain itu juga dilakukan normalitas dan uji heteroskedasitas.

Hasil estimasi terhadap tujuh persamaan tersebut menunjukkan nilai koefisien determinasi $\left(\mathrm{R}^{2}\right)$ berkisar antara 0.31435 sampai 0.6189 . Hal ini mengindikasikan bahwa peubah-peubah penjelas yang dimasukan kedalam model dapat menjelaskan variasi pangsa pengeluaran komoditas pangan pokok sekitar 31.43 persen sampai 61.89 persen, sedangkan sisanya dijelaskan oleh faktor lainnya yang tidak dimasukan kedalam model.

Hasil uji normalitas dengan menggunakan Shapiro Wilk Test dan uji homoskedastisitas dengan menggunakan kebalikannya (uji heteroskedastisitas) menunjukkan bahwa Pr > ChiSq yang berbeda nyata dengan nol pada taraf 5\%. Hal ini mengindikasikan bahwa data berdistribusi normal dan tidak terjadi masalah heteroskedastisitas sehingga layak untuk dinterpretasikan.

\section{Pola Konsumsi Rumahtangga}

Hasil analisis rata-rata jumlah konsumsi pangan pokok per kapita menurut kelompok pendapatan menunjukkan bahwa semakin tinggi pendapatan jumlah konsumsi per kapita perbulan ketujuh komoditas yang dianalisis tersebut memperlihatkan semakin besar jumlah komoditas yang dikonsumsi rata-rata per kapita per bulan. Hal ini memperlihatkan bahwa semakin tinggi pendapatan menunjukkan semakin tinggi jumlah permintaan (konsumsi) untuk komoditas pangan. Hal ini mengandung pengertian bahwa rumahtangga Provinsi Riau pola konsumsinya masih untuk pemenuhan kebutuhan pangan.

Selanjutnya pengalokasian pendapatan proporsi untuk pangan lebih besar menunjukan bahwa rumahtangga tersebut belum sejahtera. Pendapatan dapat dijadikan sebagai indikator tingkat kesejahteraan masyarakat [5], [34]-[38]. 
Tabel 1. Rata-rata Jumlah Konsumsi Pangan Pokok Per Kapita Menurut Kelompok Pendapatan.

\begin{tabular}{|l|c|c|c|c|c|c|c|}
\hline $\begin{array}{c}\text { Kelompok } \\
\text { Pendapatan }\end{array}$ & $\begin{array}{c}\text { Susu } \\
(\mathbf{K g})\end{array}$ & $\begin{array}{c}\text { Beras } \\
\text { dan } \\
\text { Sagu } \\
(\mathbf{K g})\end{array}$ & $\begin{array}{c}\text { Daging } \\
\text { Sapi dan } \\
\text { Ayam } \\
(\mathbf{K g})\end{array}$ & $\begin{array}{c}\text { Gara } \\
\mathbf{m} \\
(\mathbf{K g})\end{array}$ & $\begin{array}{c}\text { Gula } \\
\text { Pasir } \\
(\mathbf{K g})\end{array}$ & $\begin{array}{c}\text { Minyak } \\
\text { Goreng } \\
(\mathbf{K g})\end{array}$ & $\begin{array}{c}\text { Sayur } \\
\text { dan } \\
\text { Buah } \\
(\mathbf{K g})\end{array}$ \\
\hline Rendah & 1.64 & 6.14 & 1.07 & 1.47 & 0.81 & 1.36 & 16.08 \\
\hline Sedang & 1.98 & 7.49 & 1.45 & 1.97 & 0.97 & 1.67 & 21.22 \\
\hline Tinggi & 2.47 & 10.57 & 1.59 & 2.28 & 1.31 & 2.24 & 23.44 \\
\hline
\end{tabular}

Sumber : Susenas, data diolah.

Hasil Rata-rata pengeluaran perkapita rumahtangga untuk komoditas terpilih menurut tingkat pendidikan Ibu rumahtangga. Konsumsi pangan sumber protein, vitamin/mineral yaitu susu dan daging sapi dan ayam, sayur-sayuran serta buah-buahan dari Ibu rumahtangga berpendidikan menengah keatas menunjukkan peningkatan kecukupan gizi yang lebih membaik dari pada Ibu rumahtangga yang berpendidikan menegah kebawah, hal ini dilihat dari besaran pengeluaran untuk konsumsi komoditas tersebut semakin tinggi tingkat pendidikan rumahtangga menunjukkan semakin tinggi pengeluaran susu, daging sapi dan ayam, sayur-sayuran serta buah-buahan. Untuk komoditas garam, gula pasir, sayur dan buah tidak terjadi perbedaan yang cukup berarti antara pendidikan menengah kebawah dan pendidikan menengah keatas. Pada pendidikan menegah kebawah komoditas beras dan sagu, dan sayur dan buah masih merupakan komoditas utama.

Tabel 2. Rata-rata Pengeluaran Konsumsi Pangan Pokok Perkapita Per Bulan Menurut Tingkat Pendidikan Ibu Rumahtangga.

\begin{tabular}{|l|c|c|c|c|c|c|c|}
\hline Kelompok Pendapatan & $\begin{array}{c}\text { Susu } \\
(\mathbf{K g})\end{array}$ & $\begin{array}{c}\text { Beras } \\
\text { dan } \\
\text { Sagu } \\
(\mathbf{K g})\end{array}$ & $\begin{array}{c}\text { Daging } \\
\text { Sapi } \\
\text { dan } \\
\text { Ayam } \\
(\mathbf{K g})\end{array}$ & $\begin{array}{c}\text { Garam } \\
(\mathbf{K g})\end{array}$ & $\begin{array}{c}\text { Gula } \\
\text { Pasir } \\
(\mathbf{K g})\end{array}$ & $\begin{array}{c}\text { Minyak } \\
\text { Goreng } \\
(\mathbf{L t r})\end{array}$ & $\begin{array}{c}\text { Sayur } \\
\text { dan } \\
\text { Buah } \\
\text { (Kg) }\end{array}$ \\
\hline Menengah ke bawah & 20.495 & 39.655 & 22.566 & 1.328 & 4.694 & 26.228 & 46.322 \\
\hline Menengah ke atas & 22.128 & 37.870 & 27.571 & 1.328 & 4.383 & 24.968 & 47.456 \\
\hline
\end{tabular}

Sumber : Susenas, data diolah.

\section{Prilaku Konsumsi Pangan Pokok}

\section{Konsumsi Beras dan Sagu}

Peubah yang signifikan mempengaruhi konsumsi beras dan sagu rumahtangga di Provinsi Riau adalah harga beras dan sagu, harga daging sapi dan ayam, harga garam, harga minyak goreng, dan harga sayur-sayuran dan buah-buahan. Tanda dan besaran parameter dugaan berturut-turut sebesar 0.0191, $0.0038,-0.0009,-0.0065$ dan 0.0062. Parameter dugaan harga beras dan sagu sebesar 0.0191 mengandung pengertian bahwa apabila harga beras dan sagu meningkat sebesar satu rupiah maka pengeluaran konsumsi beras dan sagu meningkat sebesar 0.0191 rupiah. Hal ini terjadi karena beras dan sagu merupakan komoditas sumber kalori utama rumahtangga di Provinsi Riau. Rumahtangga akan berusaha mempertahankan jumlah konsumsinya, sehingga apabila harga meningkat maka pengeluaran konsumsinya juga ikut meningkat [22], [39]. Selanjutnya tanda negatif parameter dugaan harga daging sapi dan ayam, harga garam, dan harga minyak goreng mengindikasikan bahwa komoditas beras dan sagu berkomplemen dengan ketiga komoditas (kelompok komoditas) tersebut. 
Sebaliknya tanda positif dari parameter harga sayur-sayuran dan buah-buahan mengindikasikan bahwa komoditas beras dan sagu bersubstitusi dengan komoditas ini.

Tabel 3. Pendugaan Parameter Pangsa Komoditas Menggunakan Metode SUR.

\begin{tabular}{|c|c|c|c|c|c|c|c|}
\hline Variabel & $\begin{array}{l}\text { Beras } \\
\text { dan } \\
\text { Sagu } \\
\end{array}$ & Susu & $\begin{array}{l}\text { Daging } \\
\text { Sapi \& } \\
\text { Ayam }\end{array}$ & Garam & $\begin{array}{l}\text { Gula } \\
\text { Pasir }\end{array}$ & $\begin{array}{l}\text { Minyak } \\
\text { Goreng }\end{array}$ & $\begin{array}{c}\text { Sayur } \\
\text { dan } \\
\text { Buah }\end{array}$ \\
\hline Intercept & $0.2952 \mathbf{c}$ & $0.1671 \mathrm{c}$ & $-0.0543 \mathbf{c}$ & $0.0147 \mathbf{c}$ & $0.0429 \mathbf{c}$ & 0.2081 c & $0.3264 \mathbf{c}$ \\
\hline Harga beras dan sagu & $0.0191 \mathrm{c}$ & -0.0005 & $-0.0038 \mathbf{a}$ & $-0.0009 \mathbf{c}$ & -0.0011 & $-0.0065 \mathbf{c}$ & $-0.0062 \mathbf{b}$ \\
\hline Harga susu & -0.0005 & $\begin{array}{r}0.0155 \\
\mathbf{c}\end{array}$ & $-0.0021 \mathbf{b}$ & -0.0001 & -0.0003 & $-0.0034 \mathbf{c}$ & $-0.0091 \mathbf{c}$ \\
\hline $\begin{array}{l}\text { Harga daging sapi\& } \\
\text { ayam }\end{array}$ & $-0.0038 \mathbf{a}$ & $-\overline{0.0021 \mathbf{b}}$ & $0.0124 \mathbf{c}$ & -0.0001 & 0.0006 & 0.0011 & $-0.0082 \mathbf{c}$ \\
\hline Harga garam & $-0.0009 \mathbf{c}$ & -0.0001 & -0.0001 & $0.0013 \mathrm{c}$ & 0 & 0 & $-0.0003 \mathbf{a}$ \\
\hline Harga gula pasir & -0.0011 & -0.0003 & 0.0006 & -0.0001 & $0.0016 \mathrm{c}$ & $-0.0015 \mathrm{c}$ & 0.0007 \\
\hline Harga minyak goring & $-0.0065 \mathbf{c}$ & $0.0034 \mathbf{c}^{-}$ & 0.0011 & 0 & $-0.0015 \mathbf{c}$ & $0.0112 \mathbf{c}$ & -0.0015 \\
\hline Harga Sayur dan Buah & $-0.0062 \mathbf{b}$ & $\begin{array}{r}-0.0091 \\
\mathbf{c}\end{array}$ & $-0.0082 \mathbf{c}$ & $-0.0003 \mathbf{a}$ & 0.0007 & -0.0015 & $0.0246 \mathrm{c}$ \\
\hline Lnp & $-0.0115 \mathbf{c}$ & $\begin{array}{r}-0.0098 \\
\mathbf{c}\end{array}$ & $0.0364 \mathbf{c}$ & $-0.0008 \mathbf{c}$ & $-0.0024 \mathbf{c}$ & $-0.0143 \mathbf{c}$ & $0.0025 \mathbf{c}$ \\
\hline Jmlh anggota rt & $-0.0478 \mathbf{c}$ & $\begin{array}{r}-0.0125 \\
\mathbf{c}\end{array}$ & $-0.2489 \mathbf{c}$ & 0.0002 & $\begin{array}{r}-0.0013 \\
\text { b }\end{array}$ & 0.0037 & $-0.1523 \mathbf{c}$ \\
\hline Dummy pendidikan & $-0.0153 \mathbf{c}$ & -0.0038 & $-0.0450 \mathbf{c}$ & 0.0002 & -0.0005 & -0.0002 & $-0.0209 \mathbf{c}$ \\
\hline Dummy pendapatan $\mathrm{d} 2$ & $\begin{array}{r}-0.0060 \\
\mathbf{b} \\
\end{array}$ & 0 & $-0.0216 \mathbf{c}$ & -0.0001 & 0.0001 & -0.0022 & $-0.0211 \mathbf{c}$ \\
\hline Dummy pendapatan $\mathrm{d} 3$ & $-0.0100 \mathbf{c}$ & 0.0011 & $-0.0555 \mathrm{c}$ & 0 & 0.0002 & 0.0005 & $-0.0418 \mathbf{c}$ \\
\hline
\end{tabular}

Tabel 4. Elastisitas Harga Sendiri dan Harga Silang Beberapa Komoditas Pangan Pokok.

\begin{tabular}{|c|c|c|c|c|c|c|c|}
\hline \multirow[b]{2}{*}{ Komoditas } & \multicolumn{7}{|c|}{ Harga Komoditas } \\
\hline & $\begin{array}{l}\text { Beras } \\
\text { dan } \\
\text { Sagu }\end{array}$ & Susu & $\begin{array}{l}\text { Daging } \\
\text { Sapi \& } \\
\text { Ayam }\end{array}$ & Garam & $\begin{array}{l}\text { Gula } \\
\text { Pasir }\end{array}$ & $\begin{array}{l}\text { Minyak } \\
\text { Goreng }\end{array}$ & $\begin{array}{c}\text { Sayur } \\
\text { Sayuran } \\
\text { \& Buah- } \\
\text { buahan } \\
\end{array}$ \\
\hline Beras dan Sagu & -0.6824 & -0.0031 & -0.0829 & -0.0138 & -0.018 & -0.0948 & -0.1025 \\
\hline Susu & 0.0063 & -0.5066 & -0.1054 & -0.0027 & -0.0091 & -0.0877 & -0.29 \\
\hline Daging Sapi \& Ayam & -0.0863 & -0.0484 & -0.6945 & -0.0019 & 0.0175 & 0.048 & -0.2303 \\
\hline Garam & -0.0675 & 0.1037 & -0.6367 & -0.4052 & 0.0054 & 0.2911 & -0.2233 \\
\hline Gula Pasir & -0.0559 & 0.0008 & -0.0919 & -0.0007 & -0.7813 & -0.1201 & 0.069 \\
\hline Minyak Goreng & -0.1379 & -0.074 & -0.0043 & 0.0008 & -0.0358 & -0.7046 & -0.0407 \\
\hline Sayur \& Buah & -0.074 & -0.1192 & -0.1281 & -0.004 & 0.0099 & -0.0124 & -0.6702 \\
\hline
\end{tabular}

Tabel 5. Elastisitas Pendapatan Beberapa Komoditas Pangan Pokok.

\begin{tabular}{|l|r|}
\hline \multicolumn{1}{|c|}{ Komoditas } & Elastisitas Pendapatan \\
\hline Beras dan Sagu & 0.8158 \\
\hline Susu & 0.6937 \\
\hline Daging Sapi \& Ayam & 2.0029 \\
\hline Garam & 0.6330 \\
\hline Gula Pasir & 0.6819 \\
\hline Minyak Goreng & 0.6578 \\
\hline Sayur Sayuran \& Buah-buahan & 1.0341 \\
\hline
\end{tabular}

Elasitisitas harga sendiri dan harga silang (lihat Tabel 4 dan Tabel 5) seluruhnya lebih kecil dari satu (dalam nilai absolut). Hal ini mengindikasikan bahwa pengaruh peubah-peubah tersebut tidak responsif terhadap konsumsi beras dan sagu oleh rumahtangga di Provinsi Riau. 
Sedangkan hasil dari perhitungan elastisitas pendapatan juga besaran nilai elastisitasnya kecil dari satu. Hal ini juga mengandung pengertian bahwa elastisitas pendapatan tidak responsif terhadap konsumsi beras dan sagu rumahtangga di Provinsi Riau.

\section{Konsumsi Susu}

Peubah yang signifikan mempengaruhi konsumsi susu rumahtangga di Provinsi Riau adalah harga susu, harga daging sapi dan ayam, harga minyak goreng, dan harga sayur-sayuran dan buah-buahan. Tanda dan besaran parameter dugaan berturut-turut sebesar 0.0155, -0.0021, dan -0.0034. Hal ini terjadi karena susu merupakan komoditas sumber protein utama rumahtangga di Provinsi Riau. Rumahtangga akan berusaha mempertahankan jumlah konsumsinya, sehingga apabila harga meningkat maka pengeluaran konsumsinya juga ikut meningkat. Selanjutnya tanda negatif parameter dugaan harga harga daging sapi dan ayam, harga minyak goreng, dan harga sayur-sayuran dan buah-buahan mengindikasikan bahwa komoditas susu berkomplemen dengan ketiga komoditas tersebut. Sebaliknya tanda positif dari parameter harga sayur-sayuran dan buah-buahan mengindikasikan bahwa komoditas beras dan sagu bersubstitusi dengan komoditas ini.

Elasitisitas harga sendiri dan harga silang (lihat Tabel 4 dan Tabel 5) seluruhnya besaran nilainya lebih kecil dari satu (dalam nilai absolut), hal ini senada dengan konsumsi beras dan sagu. Hal ini mengindikasikan bahwa pengaruh peubah-peubah tersebut tidak responsif terhadap konsumsi susu oleh rumahtangga di Provinsi Riau. Sedangkan hasil perhitugan menunjukan elastisitas pendapatan juga besaran nilai elastisitasnya kecil dari satu. Hal ini juga mengandung pengertian bahwa elastisitas pendapatan tidak responsif terhadap konsumsi susu rumahtangga di Provinsi Riau.

\section{Konsumsi Daging Sapi dan Ayam}

Peubah yang signifikan mempengaruhi konsumsi Daging Sapi dan Ayam rumahtangga di Provinsi Riau adalah harga daging sapi dan ayam, harga susu, harga beras dan sagu, dan harga sayur-sayuran dan buah-buahan. Tanda dan besaran parameter dugaan berturut-turut sebesar 0.0124, -0.021, -0.0038, dan -0.0082. Hal ini terjadi karena susu merupakan komoditas sumber protein rumahtangga di Provinsi Riau. Rumahtangga akan berusaha mempertahankan jumlah konsumsinya, sehingga apabila harga meningkat maka pengeluaran konsumsinya juga ikut meningkat. Selanjutnya tanda negatif parameter dugaan harga susu, harga beras dan sagu, dan harga sayur-sayuran dan buah-buahan mengindikasikan bahwa komoditas daging sapi dan ayam berkomplemen dengan ketiga komoditas tersebut. Sebaliknya tanda positif dari parameter harga sayur-sayuran dan buah-buahan mengindikasikan bahwa komoditas beras dan sagu bersubstitusi dengan komoditas ini. 
Elasitisitas harga sendiri dan harga silang (lihat Tabel 4 dan Tabel 5) seluruhnya besaran nilainya lebih kecil dari satu (dalam nilai absolut), hal ini senada dengan konsumsi beras dan sagu dan susu. Hal ini mengindikasikan bahwa pengaruh peubah-peubah tersebut tidak responsif terhadap konsumsi daging sapi dan ayam oleh rumahtangga di Provinsi Riau. Sedangkan elastisitas pendapatan dari hasil perhitungan besaran nilai elastisitasnya besar dari satu. Hal ini juga mengandung pengertian bahwa elastisitas pendapatan responsif terhadap konsumsi daging sapi dan ayam rumahtangga di Provinsi Riau.

\section{Konsumsi Garam}

Peubah yang signifikan mempengaruhi konsumsi garam rumahtangga di Provinsi Riau adalah harga garam, harga beras dan sagu, dan harga sayur -sayuran dan buah-buahan. Tanda dan besaran parameter dugaan berturut-turut sebesar 0.0013, -0.0009 , dan -0.0003 . Hal ini terjadi karena garam merupakan komoditas sumber kebutuhan utama garam beriodium rumahtangga di Provinsi Riau. Rumahtangga akan berusaha mempertahankan jumlah konsumsinya, sehingga apabila harga meningkat maka pengeluaran konsumsinya juga ikut meningkat. Selanjutnya tanda negatif parameter dugaan harga beras dan sagu, dan harga sayur sayuran dan buah-buahan. mengindikasikan bahwa komoditas garam berkomplemen dengan kedua komoditas (kelompok komoditas) tersebut. Sebaliknya tanda positif dari parameter harga sayur-sayuran dan buah-buahan mengindikasikan bahwa komoditas beras dan sagu bersubstitusi dengan komoditas ini.

Elasitisitas harga sendiri dan harga silang (lihat Tabel 4 dan Tabel 5) seluruhnya besaran nilainya lebih kecil dari satu (dalam nilai absolut), hal ini senada dengan konsumsi beras dan sagu, konsumsi susu, dan konsumsi daging sapi dan ayam. Hal ini mengindikasikan bahwa pengaruh peubah-peubah tersebut tidak responsif terhadap konsumsi garam oleh rumahtangga di Provinsi Riau. Sedangkan hasil perhitugan menunjukan elastisitas pendapatan juga besaran nilai elastisitasnya kecil dari satu hal ini senada dengan elastisitas pendapatan beras dan sagu dan susu. Hal ini juga mengandung pengertian bahwa elastisitas pendapatan tidak responsif terhadap konsumsi garam rumahtangga di Provinsi Riau.

\section{Konsumsi Gula Pasir}

Peubah yang signifikan mempengaruhi konsumsi gula pasir rumahtangga di Provinsi Riau adalah harga gula pasir dan harga minyak goreng. Tanda dan besaran parameter dugaan berturut-turut sebesar 0.0016, dan -0.0015. Hal ini terjadi karena gula pasir merupakan komoditas kebutuhan pokok rumahtangga di Provinsi Riau. Rumahtangga akan berusaha mempertahankan jumlah konsumsinya, sehingga apabila harga meningkat maka pengeluaran konsumsinya juga ikut meningkat. Selanjutnya tanda negatif parameter dugaan harga minyak goreng. Hal ini mengindikasikan bahwa komoditas gula pasir berkomplemen dengan komoditas 
minyak goreng (kelompok komoditas) tersebut. Sebaliknya tanda positif dari parameter harga sayur-sayuran dan buah-buahan mengindikasikan bahwa komoditas beras dan sagu bersubstitusi dengan komoditas ini.

Elasitisitas harga sendiri dan harga silang (lihat Tabel.. dan Tabel..) seluruhnya besaran nilainya lebih kecil dari satu (dalam nilai absolut. Hal ini mengindikasikan bahwa pengaruh peubah-peubah tersebut tidak responsif terhadap konsumsi gula pasir oleh rumahtangga di Provinsi Riau. Sedangkan hasil perhitugan menunjukan elastisitas pendapatan juga besaran nilai elastisitasnya kecil dari satu. Hal ini juga mengandung pengertian bahwa elastisitas pendapatan tidak responsif terhadap konsumsi gula pasir rumahtangga di Provinsi Riau.

\section{Konsumsi Minyak Goreng}

Peubah yang signifikan (faktor dominan) mempengaruhi konsumsi minyak goreng rumahtangga di Provinsi Riau adalah harga minyak goreng, harga susu, harga beras dan sagu, dan gula pasir. Tanda dan besaran parameter dugaan berturut-turut sebesar0.0118, -0.0034, 0.0065, dan -0.0015. Hal ini terjadi karena minyak goreng merupakan komoditas kebutuhan pokok rumahtangga di Provinsi Riau. Rumahtangga akan berusaha mempertahankan jumlah konsumsinya, sehingga apabila harga meningkat maka pengeluaran konsumsinya juga ikut meningkat. Selanjutnya tanda negatif parameter dugaan harga susu, harga beras dan sagu, dan gula pasir. Hal ini mengindikasikan bahwa komoditas minyak goreng berkomplemen dengan ketiga komoditas (kelompok komoditas) tersebut. Sebaliknya tanda positif dari parameter harga sayur-sayuran dan buah-buahan mengindikasikan bahwa komoditas beras dan sagu bersubstitusi dengan komoditas ini

Elasitisitas harga sendiri dan harga silang (lihat Tabel 4 dan Tabel 5) seluruhnya besaran nilainya lebih kecil dari satu (dalam nilai absolut). Hal ini mengindikasikan bahwa pengaruh peubah-peubah tersebut tidak responsif terhadap konsumsi minyak goreng oleh rumahtangga di Provinsi Riau. Sedangkan hasil perhitugan menunjukan elastisitas pendapatan juga besaran nilai elastisitasnya kecil dari satu. Hal ini juga mengandung pengertian bahwa elastisitas pendapatan tidak responsif terhadap konsumsi minyak goreng rumahtangga di Provinsi Riau.

\section{Konsumsi Sayur-sayuran dan Buah-Buahan}

Peubah yang signifikan (faktor dominan) mempengaruhi konsumsi sayur-sayuran dan buah-buahan rumahtangga di Provinsi Riau adalah harga sayur-sayuran dan buah-buahan harga susu, harga beras dan sagu, harga daging sapi dan ayam, dan harga garam. Tanda dan besaran parameter dugaan berturut-turut sebesar 0.0246, -0.0091, -0.0062, dan -0.0003. Hal ini terjadi karena sayu-sayur dan buah-buahan merupakan komoditas kebutuhan sumber vitamin dan mineral rumahtangga di Provinsi Riau. Rumahtangga akan berusaha mempertahankan jumlah konsumsinya, sehingga apabila harga meningkat maka pengeluaran konsumsinya juga ikut 
meningkat. Selanjutnya tanda negatif parameter dugaan harga susu, harga beras dan sagu, harga daging sapi dan ayam, dan harga garam Hal ini mengindikasikan bahwa komoditas harga sayur-sayuran dan buah-buahan berkomplemen dengan keempat komoditas (kelompok komoditas) tersebut. Sebaliknya tanda positif dari parameter harga sayur-sayuran dan buahbuahan mengindikasikan bahwa komoditas beras dan sagu bersubstitusi dengan komoditas ini

Elasitisitas harga sendiri dan harga silang (lihat Tabel 4 dan Tabel 5) seluruhnya besaran nilainya lebih kecil dari satu (dalam nilai absolut). Hal ini mengindikasikan bahwa pengaruh peubah-peubah tersebut tidak responsif terhadap konsumsi sayur-sayuran dan buahbuahan oleh rumahtangga di Provinsi Riau. Sedangkan elastisitas pendapatan dari hasil perhitungan besaran nilai elastisitasnya besar dari satu. Hal ini juga mengandung pengertian bahwa elastisitas pendapatan responsif terhadap konsumsi daging sapi dan ayam rumahtangga di Provinsi Riau.

\section{KESIMPULAN}

Hasil penelitian menunjukkan bahwa:

1. Semakin tinggi tingkat pendapatan, proporsi pengeluaran pangan cenderung menurun. Semakin tinggi pendidikan ibu rumah tangga semakin banyak konsumsi susu, daging sapi dan ayam, sayur-sayuran serta buah-buahan, sedangkan konsumsi beras dan sagu, gula pasir, dan minyak goreng cenderung menurun.

2. Faktor-faktor dominan yang mempengaruhi perilaku konsumsi pangan pokok oleh rumahtangga di Provinsi. Pertama, pengeluaran konsumsi beras dan sagu dominan dipengaruhi oleh harganya sendiri, harga daging sapi dan ayam, harga garam, harga minyak goreng, dan harga sayur-sayuran dan buah-buahan. Kedua, pengeluaran konsumsi susu dominan dipengaruhi oleh harga susu, harga daging sapi dan ayam, harga minyak goreng, dan harga sayur-sayuran dan buah-buahan. Ketiga, pengeluran konsumsi daging sapi dan ayam dominan dipengaruhi oleh harganya sediri, harga susu, harga beras dan sagu, dan harga sayur-sayuran dan buah-buahan. Keempat, pengeluaran konsumsi garam dominan dipengaruhi oleh harganya sendiri, harga beras dan sagu, dan harga sayursayuran dan buah-buahan. Kelima, pengeluaran konsumsi gula pasir dominan dipengaruhi oleh harganya sendiri, dan harga minyak goreng. Keenam, pengeluaran konumsi minyak goreng dominan dipengaruhi oleh harganya sendiri, harga susu, harga beras dan sagu, dan harga gula pasir. Dan ketujuh, pengeluaran konsumsi sayur-sayuran dan buah-buahan dominan dipengaruhi oleh harganya sendiri, harga susu, harga beras dan sagu, harga daging sapi dan ayam, dan harga garam. 
3. Berdasarkan hasil perhitungan elastisitas pengeluaran konsumsi masing-masing komoditas yang diamati tidak responsif terhadap perubahan harga sendiri maupun harga komoditas lainnya. Sementara itu, elastisitas pendapatan menunjukkan daging sapi dan ayam, serta sayur-sayuran dan buah-buahan, responsif terhadap perubahan pendapatan.

\section{DAFTAR PUSTAKA}

[1] A. Koutsoyianis, Modern Microeconomics 2nd Edition, 2nd Editio. London and New York: The Macmillan Press Ltd, 1979.

[2] R. G. Lipsey, Microeconomics, 14th Canadian Edition. Canada: Pearson Education, 2013.

[3] R. S. Pindyck and D. L. Rubinfeld, Microeconomics Eighth Edition. London New York: Pearson Education Limited, 2014.

[4] P. L. Ischak, Analisis Permintaan dan Pola Konsumsi Pangan Di Provinsi Jambi. Bogor: Tesis Magister Sains. Program Pascasarjana, Institut Pertanian Bogor, 2005.

[5] L. Blanciforti and G. Richard, "An Almost Ideal Demand System Incorporating Habits: An Analysis of Expenditures on Food and Aggregate Commodity Groups," Rev. Econ. Stat., vol. 65, no. 3, pp. 511-515, 1983.

[6] A. Bilgic and S. T. Yen, "Household food demand in Turkey: A two-step demand system approach," Food Policy, vol. 43, pp. 267-277, 2013.

[7] S. Kabe and Y. Kanazawa, "Estimating the Markov-switching almost ideal demand systems: a Bayesian approach,” Empir. Econ., vol. 47, no. 4, pp. 1193-1220, 2013.

[8] F. A. S. Bokhari and F. Mariuzzo, "Demand estimation and merger simulations for drugs: Logits v. AIDS," Int. J. Ind. Organ., 2018.

[9] O. Putna, F. Janošt’ák, R. Šomplák, and M. Pavlas, "Demand modelling in district heating systems within the conceptual design of a waste-to-energy plant," Energy, vol. 163, pp. 1125-1139, 2018.

[10] H. Zhang, J. Wang, and W. Martin, "Factors affecting households' meat purchase and future meat consumption changes in China: a demand system approach," J. Ethn. Foods, vol. 5, no. 1, pp. 24-32, 2018.

[11] M. A. Tovar Reaños and N. M. Wölfing, "Household energy prices and inequality: Evidence from German microdata based on the EASI demand system," Energy Econ., vol. 70, pp. 84-97, 2018.

[12] D. Hummels and K. Y. Lee, "The income elasticity of import demand: Micro evidence and an application," J. Int. Econ., vol. 113, pp. 20-34, 2018.

[13] S. Herminghaus, "Mean field theory of demand responsive ride pooling systems," Transp. Res. Part A Policy Pract., vol. 119, no. October 2018, pp. 15-28, 2019.

[14] K. ichi Mizobuchi and H. Tanizaki, "On estimation of almost ideal demand system using moving blocks bootstrap and pairs bootstrap methods," Empir. Econ., vol. 47, no. 4, pp. 1221-1250, 2013.

[15] M. Aepli, "Consumer demand for alcoholic beverages in Switzerland: a two-stage quadratic almost ideal demand system for low, moderate, and heavy drinking households," Agric. Food Econ., vol. 2, no. 1, 2014.

[16] C. Alexandri, B. Păuna, and L. Luca, "An Estimation of Food Demand System in Romania - Implications for Population's Food Security," Procedia Econ. Financ., vol. 22, no. November 2014, pp. 577-586, 2015.

[17] J. J. García-del-Hoyo, R. Jiménez-Toribio, and P. Guillotreau, "A demand analysis of the Spanish canned tuna market," Mar. Policy, vol. 86, no. April, pp. 127-133, 2017.

[18] G. B. M. A. Litjens, E. Worrell, and W. G. J. H. M. van Sark, "Influence of demand patterns on the optimal orientation of photovoltaic systems," Sol. Energy, vol. 155, pp. 1002-1014, 2017. 
[19] C. M. Guerrero-López, M. Unar-Munguía, and M. A. Colchero, "Price elasticity of the demand for soft drinks, other sugar-sweetened beverages and energy dense food in Chile," BMC Public Health, vol. 17, no. 1, pp. 1-8, 2017.

[20] N. Stacey, A. Tugendhaft, and K. Hofman, "Sugary beverage taxation in South Africa: Household expenditure, demand system elasticities, and policy implications," Prev. Med. (Baltim)., vol. 105, pp. S26-S31, 2017.

[21] A. Saayman, A. Viljoen, and M. Saayman, "Africa's outbound tourism: An Almost Ideal Demand System perspective," Ann. Tour. Res., vol. 73, no. March, pp. 141-158, 2018.

[22] H. Heriyanto, "Prilaku Konsumsi Pangan Sumber Karbohidrat Rumahtangga Petani Kelapa Sawit di Kecamatan Kandis Kabupaten Siak," J. Ilm. Pertan., vol. 13, no. 2, pp. 22-30, 2016.

[23] H. Heriyanto and Asrol, "Pola Konsumsi Pangan Rumahtangga Petani Kelapa Sawit Di Kecamatan Minas Kabupaten Siak Riau," in Prosiding seminar nasional hasil penelitian sosial ekonomi pertanian, 2016, pp. 650-661.

[24] D. Gujarati, Econometric By Example. New York: McGraw-Hill/Irwin, a Business Unit of The McGraw-Hill Companies.Avenue of the Americas, 2011.

[25] J. M. Henderson and R. E. Quandt, Mocroeconomic Theory A. Mathematical Approach, Third Edit. Kogakusha, Ltd. Tokyo: International Stident Edition. Mc. Graw Hill, 1980.

[26] C. Mukherjee, H. White, and W. Marc, Econometrics and_Data Analysis for Developing Countries. London and New York: Routledge is an imprint ofthe Taylor \& Francis Group, an informa business, 2015.

[27] R. S. Pindyck and D. L. Rubinfeld, Econometric Model and Econometric Forecasts, Fourth Edi. New York: McGraw-Hill International Editions, 1998.

[28] R. . Thomas, Modern Econometrics an Introduction. Harlow: Addison Wesley Longman, 1977.

[29] H. . Varian, Macroeconomic Analysis, 2nd Editio. New York: W.W. Norton and Company, 1984.

[30] M. Verbeek, A Guide to Modern Ecomometrics. Chichester: John Wiley \& Sons Ltd, 2000.

[31] M. Verbeek, A guide to modern econometrics, Fifth Edit. Rotterdam: John Wiley \& Sons Ltd, 2017.

[32] D. Gujarati, Basic Econometrics. New York: McGraw-Hill/Irwin, a business unit of The McGraw-Hill Companies, Inc., 1221 Avenue of the Americas, 2008.

[33] M. Kahar, Analisis Pola Konsumsi Daerah Perkotaan dan Perdesaan Serta Keterkaitan Dengan Karakteristik Sosial Ekonomi Di Provinsi Banten. Bogor: Tesis Magister Sains. Program Pascasarjana, Institut Pertanian Bogor, 2010.

[34] J. Behringer and T. van Treeck, "Income distribution and the current account," J. Int. Econ., vol. 114, no. June 2018, pp. 238-254, 2018.

[35] J. M. Berge, M. Draxten, A. Trofholz, C. H. Bradley, K. Justesen, and A. Slattengren, "Similarities and differences between families who have frequent and infrequent family meals A qualitative investigation of low-income and minority households," Eat. Behav. An Internastional J., vol. 4, no. February 2018, pp. 1-26, 2018.

[36] E. Berisha and J. Meszaros, "Household debt, economic conditions, and income inequality: A state level analysis," Soc. Sci. J., vol. 54, no. 1, pp. 93-101, 2017.

[37] W. Dassanayake, M. K. Luckert, and S. Mohapatra, "Heterogeneity of household structures and income: Evidence from Zimbabwe and South Africa," J. Policy Model., vol. 37, no. 4, pp. 668-692, 2015.

[38] Yusmini, Khaswarina, and Maharani, "Analisis Komparatif Tingkat Kesejahteraan Rumah Tangga Petani Karet Desa Sungai Jalau Dengan Desa Teratak Kabupaten Kampar," SEPA, vol. 11, no. 1, pp. 89-97, 2014.

[39] R. B.- Prokeinova and M. Hanova, "Consumer' s behavior of the foodstuff consumption in Slovakia," Procedia - Soc. Behav. Sci., vol. 220, no. March, pp. 21-29, 2016. 